engenders in those men and women who were sustained through the last war by the ideal of a future society free of want, disease, ignorance, squalor, and idleness. How do they respond when their first sight of a hospital is of two student nurses and a patient's relative struggling with two trolleys, a closed children's ward on one side, a condemned lift on the other, and between them and the $x$ ray department an obstacle course of buckets and basins carefully positioned under a leaking roof?

I cannot tell you that, and I cannot tell you from where the people who work there get their resources of politeness and humanity. And from what I saw I cannot tell you how long everyone is prepared to stick it.

British Medical Journal, London WC1H 9JR

TONY DELAMOTHE, MD, MRCP, assistant editor

\title{
Twenty steps towards a "closed society" on health
}

\author{
RICHARD SMITH
}

\begin{abstract}
Almost by definition it is difficult to obtain information on attempts by those in power to keep information secret and stop people talking publicly. Yet every day in our conversations with doctors, administrators, researchers, and others we hear stories of suppression of information about health and the health service. Our impression, and the impression of others, is that "there is a lot of it about"perhaps more than there was. Sir Douglas Black discusses the "closed society" in a leading article (p 1582). I have compiled a list of examples to illustrate his theme and give some idea of the scale of the suppression. By its nature the list is idiosyncratic, far from complete, and may even be inaccurate in places, although it has been checked wherever possible. Written evidence is available to support many of the cases.
\end{abstract}

1. The wording of the contract of researchers funded by the Department of Health and Social Security has been changed in a way that most researchers interpret as an attempt to inhibit publication of results that may not support government policy. Previously the wording was: "any comments which the Secretary of State makes [on proposed publications] shall be considered by the researcher but the researcher shall nevertheless be able to allow publication to go forward in the original form as he thinks fit"; now the contract specifies that publication "is subject to the prior consent of the Secretary of State, which consent shall not be unreasonably withheld."

Researchers are worried not only about suppression but also that the credibility of their research may be undermined-how can the reader know whether important information has been suppressed? The possibility arises that editors of journals may decline to publish papers that may or may not have been censored, or they may demand to know whether anything has been changed. They may then wish to tell their readers that the article has been changed and to indicate where.

Researchers are also worried about delay. At the moment if the researchers do not hear back from the DHSS in 28 days they simply proceed to publication. If they must have a clear indication they may have to wait months-perhaps until long after the time when their work would have been important (or controversial).

2. Nicholas Ridley, Secretary of State for the Environment, was reported by Dr Michael O'Donnell in the Guardian (24 June, p 13) to have written to Tony Newton, Minister of Health, to ask him to "silence" Mr John Guy, an orthopaedic surgeon at the Worcester Royal Infirmary. Mr Guy had written to the people on his waiting list to say that financial cuts in the health authority meant that they could not have their hip replacement operations. He suggested that they write to their members of parliament. One patient sent a copy of Mr Guy's letter to Mr Ridley, who responded by writing to $\mathrm{Mr}$ Newton, saying "It seems to me intolerable that employees of the Health Service should openly criticise their health authorities in this sort of way."

A question was asked about the letter in the House of Lords (13 July), but the government declined to comment.

3. The attempt by Sir Brian Bailey, chairman of the Health Education Council, to block publication of the council's report on poverty and health has been extensively described in the $B M F$ and elsewhere. (As a postscript to this episode, an applicant for a job at the new Health Education Authority was asked in his interview what he would do to "shut up" critics of the authority.)

4. When Mr Victor Paige resigned as chairman of the NHS Management Board the West Midlands Regional Health Authority sent a telex to its 22 districts telling them not to comment on the matter. The regional authority said that it had received a call from the DHSS instructing them not to comment. (Reported in The Times, 5 June 1986, p 1.)

5. Mr Jeff Prosser, unit general manager of community and priority services in Tower Hamlets Health Authority, wrote to all his staff on 2 November 1987 to tell them that they are "not permitted to make contacts ... with members of parliament, newspapers, local councillors, and health authority members." He did so because of an "incident which caused the authority some embarrassment" and said that "a breach of these instructions could result in disciplinary proceedings." (I have a copy of this letter.)

6. Sir Bryan Thwaithes, chairman of Wessex Regional Health Authority, was asked (told) by the government to keep quiet after he had spoken during the election of the impossibility of NHS funds keeping up with the expectations of patients and doctors.

7. The chairmen of the London district health authorities were pressurised by the NHS Management Board not to publish their report on back to back health planning in London, which highlighted severe deficiencies in the acute hospitals in London. They published it anyway.

8. North West Hertfordshire Health Authority has three times disciplined Mr Doug Landman, St Albans branch secretary of the Confederation of Health Service Employees, for speaking to the press on conditions in Hill End Hospital.

9. Politically sensitive figures produced by the Department of Health and Social Security are often published late on Friday afternoons and placed in the House of Commons Library. The DHSS press office has only a limited version of the figures, which 
means that journalists often have little to work from except ministers' interpretations of the figures. This has happened at least twice with figures about waiting lists.

10. In 1986 the then Minister of Health, Barney Hayhoe, announced in parliament (16 May) that the Official Secrets Act covered the members of all DHSS committees. He reminded parliament that the act applied to "all official information whether or not a declaration has been signed." Professor Geoffrey Rose, the member of several advisory committees, interpreted this to mean that "all doctors who are members of any government advisory body are thus liable for prosecution and potential imprisonment if they divulge information which the government-at the time or later-decrees to be 'official.' If they discuss a problem with a colleague 'in confidence' and that colleague makes it public they are again liable for prosecution. It would be no defence that medical duty required openness." (BMF 1986;292:1594.)

11. The Office of Population Censuses and Surveys, which was set up 150 years ago to provide hard facts for informed debate, has suffered debilitating cuts and the morale of the staff has fallen very low. As a BMF leading article put it (4 July 1987, p 1), "No longer is it to be supported as the independent source of facts about health and society. The collection of data which may some time be used against a government is no longer considered value for money."

12. I was told when interviewing the Chief Scientist about health services research that the interview was conditional on my showing what I wrote to the DHSS. This condition was not applied by the Home Office, when I wrote about prisons, although I entered many prisons, including high security ones.

13. Officials at three of four London based regional health authorities claimed that they were told by the DHSS to change press releases announcing money made available for inner cities because they were not positive enough. The DHSS said that the story was a silly one and that "it is obviously important that departmental announcements should be consistent with local announcements." -(Guardian 1987 March 19:5.)

14. In November 1986 a prospective parliamentary Labour candidate for Newcastle North alleged that a DHSS report that showed high mortality from cervical cancer in the northern region had been suppressed. The DHSS argued that, although the report was not published, the information it contained was available from published sources. Either way it could not be called a constructive contribution to the health debate.

15. The first volume of the controversial official history of the National Health Service by Dr Charles Webster was sat on for two years. Approval for publication has now been given, however, and it should be published in the spring of 1988. (Dr Webster has also been given the go ahead to do a second volume that will take the history on to 1979.)

16. When cases of drug injury are settled out of court, one of the conditions is usually that plaintiffs do not talk to the press or say how much they were awarded.

17. The information used by the Committee on Safety of Medicines to decide whether to license a drug is not available for public scrutiny.

18. Earlier this month, according to the Guardian (1 December, p 5), Dr Eric Silove, a consultant paediatric cardiologist in Birmingham, was asked by the Central Birmingham Health Authority to stop commenting to the media on the case of the baby whose heart operation was repeatedly postponed.

19. Health authority meetings are divided into two parts, part II being held in camera. Health authorities are increasingly tending to discuss privatisation plans in part II of their meetings. This is done on the grounds that the information demands commercial secrecy, although often the discussions are on the general issue rather than on which company should be awarded the contract. Hastings Health Authority has done this when discussing the possibility of privatising in some way its cottage hospitals.

20. The North Western Regional Health Authority in $\mathbf{1 9 8 6}$ discussed a report on democracy in the NHS in part II of one of its meetings.

We will be pleased to hear of further examples of the debate over health being impeded.

British Medical Journal, London WC1H 9JR

RICHARD SMITH, BSC, MB, assistant editor

\section{THE WAY THEY LIVEDTHEN: VICTORIAN VALUES}

By the early 1850 s there was observable a drastic change of political mood throughout Europe, though the form this took in Britain was quite different from that of other countries. Linda Nochlin has noted of France: "After the 1848 Revolution, the worker becomes the dominant image in Realist art, partaking of both the grandeur of myth and the concreteness of reality." Britain, however, celebrated the fact that the revolution had not taken place, and Victorian painters and novelists allowed little of the "grandeur of myth" and not much more "concreteness of reality" to the worker: there was to be in Britain no very close equivalent of; say, Millet's Sower, Degas' Ironers, or Zola's Germinal, at least until Hardy's Tess of the d'Urbervilles (1891). Victorian Britain's political revolution took place in 1867 with the passing of the Reform Act which enfranchised the urban working man and established the principle (though not, for some time, the practice) of universal manhood suffrage. It is not inconceivable that the ballot-box might have been invested with something of the heroic status usually granted to the street barricade, but the extension of the franchise was carried through with little enthusiasm or confidence: it was, in the much quoted phrase of the day, "a leap in the dark." Amid the uncertainty about what kind of society was likely to emerge out of the darkness, there was a widespread conviction that political power was being shifted from the responsible few to an irresponsible and illinformed mass, a danger that Forster's great Education Bill of 1870 was intended to combat. In the 1840 s class fear had focused on an image of a violent revolutionary mob: in the 1870 s that dominant image was transformed into what Walter Bagehot described, in his introduction to the second edition of The English Constitution (1867), as "the ignorant multitude of the new constituencies."

Orgainised working class pressure played only a relatively small part in the passing of the Reform Bill, though for one moment in 1866 when a meeting of the Reform League in Hyde Park developed into a rowdy demonstration that was quickly (and unfairly) dubbed "a riot," there was a revival of the old style class panic. There were, however, several other events of 1866 that carried rather more significance for the changing national mood. For the fourth, and last, time in the nineteenth century there was a major cholera outbreak which killed more than fifteen thousand people: it was followed by a particularly harsh winter. which drove the poor, the destitute and the unemployed, visibly and vocally onto city streets. Matthew Arnold was one of the many commentators who expressed their horror at the depth of suffering the terrible winter revealed. In the topsy turvy satire of $F$ riendship's Garland Arnold himself becomes the bland Englishman who is forced to listen to the scathing criticisms of his Prussian friend Arminius: "About the state of the streets [Arminius] was bad enough, but about the poor frozen out working men who went singing without let or hindrance before our houses, he quite made my blood creep. 'The dirge of a society qui s'en va,' he used to call their pathetic songs. It is true I had always an answer for him."-PETER KEATING. In: Hard Times: Social Realism in Victorian Art, ed Julian Treuherz. London: Lund Humphries, 1986. 